\title{
UJI FITOKIMIA DAN BIOAKTIVITAS DAUN KATUK HUTAN (Phylanthus reticulatus var. Glaber)
}

\section{(Bioactive and Phytochemical Testing of Glaber leaf [Phylanthus reticulatus var. Glaber])}

\author{
ARMANSYAH K. RACHIM ${ }^{1}$, SUSILO BUDI HUSODO ${ }^{1 \bowtie}$, MULIYANA ARIFUDIN $^{1}$ \\ Jurusan Kehutanan, Fakultas Kehutanan Universitas Papua Manokwari, Papua Barat, 98314. \\ Tlp/Fax: +62986211065. \\ $\square$ Penulis Korespondensi: Email: husodo2014@gmail.com \\ Diterima: 28 Feb 2020| Disetujui: 12 Apr 2020
}

\begin{abstract}
Abstrak. Penelitian ini bertujaun untuk menguji kandungan bahan fitokimia dan bioaktif dari antioksidan, antibakteri dan toksik dari ekstrak methanol bahan daun katuk hutan (Phylanthus reticulatus var.). Hasil pengujian menunjukkan bahwa ekstrak fitokimia dari daun katuk hutan mengandung bahan alkaloids, flavonoids dan triterpenoids. Tes antioksidan memperlihatkan bahwa konsentrasi 25,50\% dan 100 ppm ekstraksi dapat menghambat radikal bebas DPPH secara berturutturut pada 79, 81 dan 89\%. Selanjutnya hasil tes antibakteri dari ekstraksi daun katuk hutan menunjukan bahwa tidak ada sifat antibakteri dimana hasil tes toksik mengindikasikan tidak adanya aktivitas toksisitas.
\end{abstract}

Kata kunci: Phylanthus reticulatus, fitokimia, bioaktif, antioksida, antibakteri dan toksisitas

\begin{abstract}
This study aims to determine the content of phytochemical and bioactivity properties of antioxidant, antibacterial and toxicity of the methanol extract of Phylanthus reticulatus var. Glaber leaf. The testing method used is the phytochemical testing, testing antioxidant, antibacterial testing dan toxicity testing. The test results show that phytochemical extracts of Phylanthus reticulatus var. Glaber leaves contain alkaloids, flavonoids and triterpenoids. Antioxidant test reveals that the concentration of 25, 50 and 100 ppm of the extract at prohibits free radical DPPH respectively around 79, 81 dan 89\%. The antibacterial testing extracts of Phylanthus reticulatus var. Glaber leaves shows that it does not have the antibacterial property. The toxicity test show that this extract does not have toxicity activity.
\end{abstract}

Keywords : Phylanthus reticulatus, phytochemical, bioactivity, antioxidant, antibacterial and toxicity

\section{PENDAHULUAN}

Keanekaragaman hayati tumbuhan tropis Indonesia merupakan sumber kekayaan yang potensial. Indonesia dikenal sebagai negara tropis yang kaya akan sumberdaya alam terutama tumbuhan. Indonesia dikenal sebagai Megabiodiversity terbesar kedua di dunia setelah Brazil (Forest Watch Indonesia 2015). Dari keanekaragaman tersebut, Indonesia mempunyai potensi yang sangat besar untuk pengembangan dan penemuan senyawasenyawa baru yaitu senyawa metabolit sekunder yang memiliki bioaktivitas dan efek yang ampuh. Diperkirakan dibumi hidup sekitar 40.000 spesies tumbuhan, dimana 30.000 jenis tananman hidup di kepulauan Indonesia. Diantara 30.000 spesies tumbuhan yang hidup dikepulauan indonesia, diketahui sekurangkurangnya 9.600 spesies tumbuhan yang 
berkhasian sebagai obat dan kurang lebih 300 spesies telah digunakan sebagai bahan obat tradisional oleh industri tradisional (Keputusan Mentri Kesehatan Republik Indonesia 2007). Menurut Kurdi (2010) diperkirakan kurang lebih 300 spesies tumbuhan yang telah digunakan sebagai bahan baku obat, namun yang tercatat sebagai produk fitofarmaka (bisa diresepkan) sebanyak 5 produk dan obat herbal terstandar sebanyak 28 produk.

Metabolisme sekunder merupakan senyawa dari hasil biogenesis dari metabolisme primer. Dalam proses metabolit sekunder pada suatu tumbuhan, tumbuhan dapat menghasilkan senyawa-senyawa yang bersifat toksik dan dapat digunakan untuk mengobati berbagai jenis penyakit pada manusia. Golongan senyawa metabolit sekunder adalah alkaloid, flavonoid, saponin, tanin, steroid dan triterpenoid (Harborne 1987). Fitokimia atau kandungan senyawa bioaktif yang terdapat dalam tumbuhan dapat memberikan kesehatan pada tubuh manusia.

Saat ini berbagai penelitian tentang tumbuhan obat sering dilakukan oleh para peneliti untuk mengetahui potensi yang ada di berbagai tumbuhan obat tersebut. Penelitian tersebut banyak dilakukan karena saat ini masih banyak jenis - jenis tanaman obat yang belum diketahui potensinya dan belum ada kajian secara ilmiah mengenai tumbuhan obat tersebut (Agromedia 2008).

Tanaman katuk hutan (Phylanthus reticulatus var. glaber) diduga berpotensi sebagai tanaman-tanaman obat. Hal ini diketahui dari pengetahuan lokal masyarakat papua yang menggunakan tumbuhan katuk hutan sebagai obat tradisional yang cukup ampuh untuk mengobati berbagai jenis penyakit diantaranya kanker payudara, kanker rahim, miom, kista, asma, dan anti alergi. Oleh karena itu perlu dilakukan penelitian secara ilmiah mengenai tumbuhan katuk hutan. Tujuan penelitian ini adalah untuk mengetahui kandungan fitokimia serta mengukur aktivitas antioksidan, antibakteri dan toksisitas dari tanaman katuk hutan. Hasil yang diharapkan dari penelitian ini adalah untuk memberikan informasi mengenai kandungan fitokimia yang dimilki oleh tanaman katuk hutan, agar penggunaannya lebih efektif dalam pengobatan.

\section{METODOLOGI PENELITIAN}

Penelitian ini dilaksanakan di Laboratorium Teknologi Hasil Hutan Fakultas Kehutanan Universitas Papua dan Laboratorium Kimia Kayu Universitas Mulawarman Samarinda yang dikerjakan selama 2 bulan lebih yang dimulai pada tanggal 28 Maret sampai dengan 11 Juni tahun 2016.

Bahan yang digunakan dalam penelitian ini adalah bagian daun dari jenis tumbuhan katuk hutan (Phylanthus reticulatus var. glaber), lakban, kantong plastik, kapas, kertas saring, nutrein broth, glukosa, agar-agar, alumunium foil. Bahan kimia yang akan digunakan adalah metanol, etanol, aquades $\mathrm{H}_{2} \mathrm{O}$, amonia $\mathrm{NH}_{3}$, asam sulfat $\mathrm{H}_{2} \mathrm{SO}_{4}$, pereaksi meyer, pereaksi dragendrof, pereaksi wagner, asam cuka $\mathrm{CH}_{3} \mathrm{COOH}$, asam klorida $\mathrm{HCL}$, etanol, magnesium $\mathrm{Mg}$, natrium clorida $\mathrm{NaCl}$, gelatin, ferrum clorida $\mathrm{FeCl}$, benzena. TTC, DPPH. Bahan uji yang digunakan adalah bakteri P.acnes, S.mutans, S. sobrinus, dan E. coli. dan organisme yang digunakan adalah larva Cyprinus carpio.

\section{Metode Penelitian}

Metode yang digunakan dalam penelitian ini adalah metode penelitian deskriptif dangan teknik analisis laboratorium.

\section{Variabel Pengamatan}

Variabel yang akan diamati dalam penelitian ini ialah golongan senyawasenyawa fitokimia yang terkandung dalam bagian daun dari tanaman katuk hutan. Serta mengukur aktivitas 
antioksidan, antibakteri dan toksisitas dari tanaman katuk hutan.

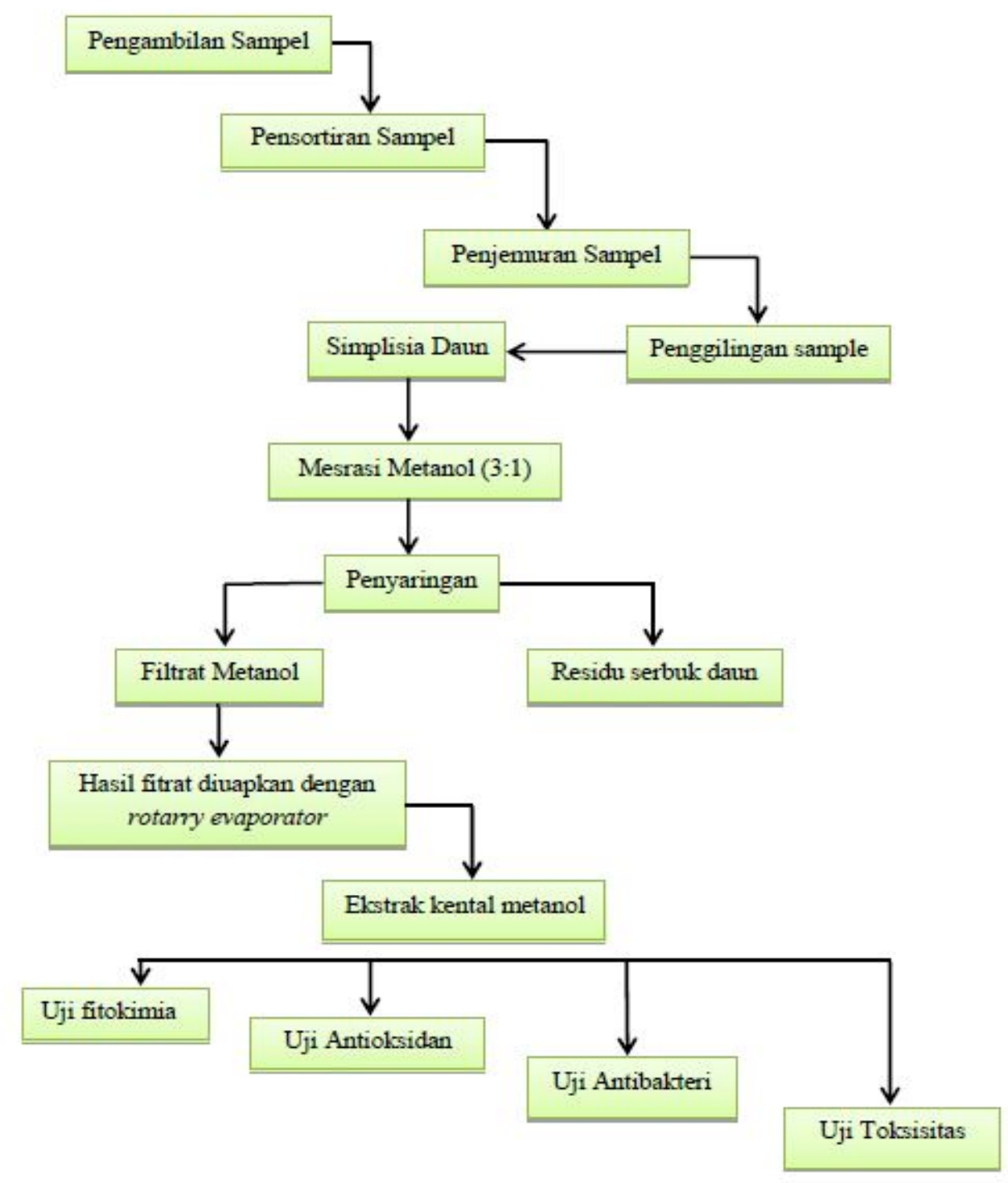

Gambar 1. Bagan alir prosedur penelitian

\section{Pengambilan Sample dan Penyiapan Simplisia}

Sample uji merupakan bagian daun dari tumbuhan katuk yang diperoleh dari kawasan hutan sekunder pantai aipiri Manokwari. Lokasi pantai aipiri dipilih dikarenakan pada kawasan tersebut terdapat banyak lahan terbuka (hutan sekunder) daerah dataran rendah dengan tekstur tanah berpasir yang merupakan tempat tumbuh dari jenis tanaman katuk hutan. Sample yang di ambil hanya berupa bagian daun, bagian daun yang di ambil disortir agar bebas dari serangga seperti semut dan sarang laba-laba. kemudian bagian daun dikeringkan melalui proses penjemuran yang dilakukan dengan cara menjemur terkena cahaya matahari yang 
bertujuan untuk mengurangi kadar air pada bagian tanaman tersebut tanpa merusak senyawa-senyawa yang terkandung didalamnya. Setelah melalui proses penjemuran, bagian tanaman tersebut digiling menggunakan mesin penggiling (hammermill) dan kemudian ditimbang sebanyak 500 gram untuk dilakukan proses maserasi pada tahap selanjutnya.

\section{Proses Ekstraksi}

\section{Maserasi}

Sample sebanyak 500 gram dari bagian daun tumbuhan $P$. reticulatus dimasukkan ke dalam toples yang berbeda dan kemudian direndam/dimaserasi dengan larutan metanol sebanyak $1500 \mathrm{ml}$ dengan perbandingan metanol berbanding sample $3: 1$ yang kemudian diaduk tiap 12 jam selama 1 hari (24 jam). Sample akan dimaserasi secara berulangulang kali hingga hasil pencampuran metanol dan sample tidak berwarna/bening.

\section{Penyaringan}

Larutan hasil maserasi/hasil ekstrak metanol disaring secara bertahap diawali dengan menggunakan corong penyaring (gough filter) nomor 1 dan kemudian hasil saringan tersebut akan disaring kembali menggunakan corong penyaring nomor 4 .

\section{Evaporasi}

Hasil ekstrak yang telah disaring akan dilakukan proses pemisahan antara larutan methanol dan ekstrak tumbuhan larut metanol dengan mengunakan alat evaporator. Alat evaporator akan memisahkan larutan metanol dan ekstrak tumbuhan larut metanol dengan cara pemanasan menggunakan air panas yang bersuhu $<50{ }^{\circ} \mathrm{C}$ dibawah dari titik didih metanol agar metanol dapat menguap sehingga terpisah dari hasil ekstrak tanpa merusak golongan struktur senyawasenyawa fitokimia yang terkandung dalam hasil ekstrak.

\section{Rendemen}

Rendemen adalah perbandingan jumlah (kuantitas) ekstrak yang dihasilkan dari tanaman yang diekstraksi. Adapun rumus yang digunakan untuk menghitung rendemen sebgai berikut :

$$
\text { Rendemen }(\%)=\frac{\text { Jumlah ekstrak yang dihasilkan }}{\text { Jumlah bahan sebelum diolah }} X 100 \%
$$

\section{Pengujian Fitokimia}

\section{Alkaloid}

Sebanyak $1 \mathrm{ml}$ ekstrak kental daun tanaman katuk hutan dari pelarut metanol dimasukkan dalam tabung reaksi dan ditambah dengan 5 tetes ammonia $\mathrm{NH}_{3}$ pekat. Setelah itu, disaring kemudian ditambah $2 \mathrm{ml}$ asam sulfat $2 \mathrm{~N}$ $\left(\mathrm{H}_{2} \mathrm{SO}_{4} \mathrm{~N}\right)$ dan dikocok hingga memberi lapisan atas dan bawah. Larutan dibagi menjadi 2 bagian, pada tabung pertama ditambahkan 1 tetes mayer, adanya alkaloid ditandai dengan terbentuknya endapan. Pada tabung kedua ditambah 1 tetes pereaksi Dragendorf dan terbentuknya endapan menandakan adanya alkaloid (Harborne 1987).

\section{Steroid dan Triterpenoid}

Sebanyak $2 \mathrm{ml}$ ekstrak kental daun tanaman katuk hutan dari pelarut metanol dimasukkan dalam tabung reaksi, kemudian ditambahkan Asam cuka $\mathrm{CH}_{3} \mathrm{COOH}$ glasial sebanyak 10 tetes dan asam sulfat $\left(\mathrm{H}_{2} \mathrm{SO}_{4}\right)$ pekat sebanyak 2 tetes. Larutan dikocok perlahan dan dibiarkan selama beberapa menit. Adanya steroid ditunjukan oleh warna biru atau hijau, sedangkan triterpenoid akan membentuk endapan atau memberikan warna merah atau ungu (Harborne 1987).

\section{Saponin}

Sebanyak 2-3 mL ekstrak kental daun tanaman katuk hutan dari pelarut metanol dimasukkan dalam tabung reaksi, kemudian ditambahkan $10 \mathrm{~mL}$ air panas $\mathrm{H}_{2} \mathrm{O}$ lalu didinginkan, kemudian dikocok kuat-kuat 
selama 10 detik lalu ditambahkan 1 tetes asam klorida HCL2 N. Uji positif ditunjukkan dengan terbentuknya buih yang stabil setinggi $1-10 \mathrm{~cm}$ selama tidak kurang dari 10 menit.

\section{Flavonoid}

Sebanyak $1 \mathrm{ml}$ ekstrak kental daun tanaman katuk hutan dari pelarut metanol dimasukkan dalam tabung reaksi, Kemudian ditambahkan dengan 5 tetes etanol, lalu dikocok sampai homogen. Setelah itu ditambah dengan serbuk magnesium $\mathrm{Mg}$ dan tambahkan 5 tetes asam klorida $\mathrm{HCl}$ pekat Jika reaksi yang terjadi menghasilkan warna kuning, orange, dan merah menandakan adanya flavonoid (Harborne 1987).

\section{Tanin}

Sebanyak $1 \mathrm{ml}$ ekstrak kental daun tanaman katuk hutan dari pelarut metanol dimasukkan dalam tabung reaksi. Kemudian ditambah 5 tetes $\mathrm{FeCl}_{3} 10 \%$, lalu dikocok sampai homogen. Diamkan sejenak dalam beberapa menit dan apabila terbentuk warna hijau menandakan adanya tanin (Harborne 1987).

\section{Pengujian Antioksidan}

Metode uji antioksidan yang digunakan berdasarkan metode Shimizu et al. (2001). Uji dilakukan dengan menggunakan UV/VIS 1200 spektrometer dengan temperatur $25^{\circ} \mathrm{C}$. siapkan tabung reaksi kemudian larutkan ekstrak kental daun dengan dimetilsulfoksida (DMSO) (larutan $100 \mathrm{ppm}$ dan $50 \mathrm{ppm}$ ). Masukkan sebanyak $33 \mu \mathrm{l}$ ekstrak daun yang telah dilarutkan dengan dimetilsulfoksida (DMSO) kedalam tabung reaksi. Setelah itu, tambahkan $467 \mu \mathrm{l}$ etanol, lalu homogenkan antara pelarut dan sample. kemudian tambahkan $500 \mu \mathrm{DPPH}$ (konsentrasi $0,0027 \%$ pada pelarut etanol) setelah itu inkubasi selama 20 menit dalam suhu ruang tanpa cahaya. Sample yang telah diinkubasi dimasukkan ke dalam cuvette untuk melakukan perhitungan perendaman DPPH menggunakan spektrofotometer. Aktivitas antioksidan dapat ditentukan melalui dekolorisasi dari DPPH pada panjang gelombang $515 \mathrm{~nm}$.

$$
\frac{\text { Abs. kontrol-Abs. sample }}{\text { Abs. kontrol }} \times 100 \%
$$

Dimana :

ABS. Kontrol $=$ Nilai absorbansi tanpa ekstrak

ABS. Sample $=$ Nilai absorbansi dengan ekstrak

Kemudian dibuat regresinya sehingga dapat dihitung harga EC50 (Effektive Contcentration = Konsentrasi yang efektif untuk menghambat atau meredam 50\% jumlah radikal bebas) (Joyeux et al. 1995).

\section{Pengujian Antibakteri}

\section{Pembuatan Stok Sample Uji}

Sampel uji diukur sebanyak $5 \mu 1$, kemudian ditambahkan larutan etanol 40\% sebanyak $1 \mathrm{ml}$ untuk membuat stok dengan konsentrasi sebesar 5000 ppm.

\section{Pembuatan Kultur Media Bakteri}

Media bakteri yang digunakan dalam pengujian ini adalah media cair dan padat. Sebanyak 8 gr nutreint broth, 10 gr glukosa, dan 20 agar-agar dimasukkan kedalam $1000 \mathrm{ml}$ aquades dan dididihkan sampai melarut sempurna, lalu dimasukkan kedalam gelas piala untuk disterilisasi dengan autoclave pada suhu $121^{\circ} \mathrm{C}$ selama 20 menit (Thiel 1999).

\section{Pembuatan Larutan Suspensi Bakteri}

Bakteri yang digunakan dalam pengujian ini adalah P.acnes, $S$. mutans, $S$. sobrinus, dan $E$. coli. Bakteri dimasukkan kedalam akuades lalu dihomogenkan. Bakteri yang digunakan di sesuaikan dengan standar Mc. Farland skala 0,5 atau pada transmitan $74 \%$ dengan panjang gelombang $600 \mathrm{~nm}$ (Prolab Diagnostics 2012).

\section{Pengujian Antimikroba}

Metode uji antibakteri yang digunakan berdasarkan metode Elkhair et al. (2010) yang sudah dimodifikasi. Stok sampel dimasukkan kedalam microplate 96 wells sebanyak $50 \mu \mathrm{l}$ 
dan dilakukan pengenceran. kemudian tambahkan media cair nutrient broth sebanyak $100 \mu \mathrm{l}$ dan $50 \mu \mathrm{l}$ larutan bakteri yang telah disuspensi dengan aquades. Microplate yang telah diinokulasi dengan bakteri diinkubasi selama 24 jam pada incubator dengan suhu 37 ${ }^{\circ} \mathrm{C}$. Satu jam sebelum proses inkubasi selesai, ditambahkan $50 \mu$ l larutan 2, 3, 5-triphenyl tetrazolium chloride (TTC). Proses akhir dari pengujian ini adalah timbulnya warna merah yang mengindikasikan masih hidupnya bakteri yang diuji pada masing-masing sampel.

\section{Pengujian Toksisitas}

Pengujian Brine shrimp lethality bioassay

Pengujian brine shrimp lethality bioassay secara luas digunakan dalam bioassay untuk senyawa bioaktif. Pengujian Toksisitas dilakukan pada Larva Cyprinus carpo dengan delapan konsentrasi $7,8,15,6,31,25,62,5$, $125,250,500$ dan 1000 ppm. Semua dosis dihitung dengan teknik pengenceran serial. Pengamatan akan dilakukan selama 24 jam, Jumlah Larva yang mati setelah 24 jam dicatat (data kematian) dan digunakan untuk menghitung LC50 dengan Program Analisis Probit Finney. LC50 lebih besar dari 1000 ppm dianggap tidak aktif (Hairani et al. 2012).

\section{Analisis Data}

Data yang diperoleh dari hasil pengamatan akan dianalisis secara desktipif dan ditampilkan secara tabulasi dan grafik pada pengujian fitokimia dan Antibakteri. sedangkan analisis regresi akan digunakan pada pengujian Toksisitas dan Antioksidan di tampilkan dalam kurva regresi.

\section{HASIL DAN PEMBAHASAN}

\section{Hasil Ekstraksi}

Metode ektraksi yang digunakan dalam penelitian ini adalah maserasi dengan menggunakan larutan polar metanol. Hasil ekstraksi dari sample tumbuhan katuk hutan melalui maserasi menggunalan pelarut diperoleh nilai MF sebesar 0,87 . Nilai moisture factor merupakan koreksi berat sampel berdasarkan nilai kadar air dari sampel. Berdasarkan tabel 3. diperoleh hasil berat ekstrak kental sebesar 136,26 gram dengan rendemen yang diperoleh mencapai 27,06 \%. Nilai rendemen menunjukan presentasi banyaknya hasil ekstrak yang diperoleh dari proses maserasi. Nilai rendemen berfungsi untuk menduga berapa banayak sampel yang diperlukan untuk menghasilkan hasil ekstraksi yang ingin diperoleh. Menurut Arifin et al. (2006), maserasi menggunakann pelarut metanol dinilai lebih menguntungkan karena sifat metanol yang mudah melarutkan senyawasenyawa yang bersifat nonpolar, semi-polar dan polar. Nilai rendemen merupakan perbandingan jumlah hasil estraksi tanaman. Semakin tinggi nilai rendemen yang dihasilkan menandakan nilai ekstraksi yang dihasilkan semakin banyak.

\section{Analisis Fitokimia}

Analisis Fitokimia telah dilakukan terhadap jenis tumbuhan katuk hutan ( $P$. reticulatus) dengan menggunakan pelarut methanol sebagai pelarut nonpolar. Hasil pengujian disajikan pada tabel dibawah ini.

Tabel 1. Hasil Pengujian fitokimia ekstrak metanol katuk hutan

\begin{tabular}{cccccccc}
\hline Nama latin & Bagian tumbuhan & Alk & Fla & Tri & Tan & Sap & Ste \\
& & & & & & & \\
\hline Phylanthus reticulatus & Daun & + & + & + & - & - & - \\
\hline
\end{tabular}

Ket: Alk (Alkaloid); Fla (flavonoid); Tri (Triterpenoid); Tan (Tanin); Sap (Saponin); Ste ( Steroid). 


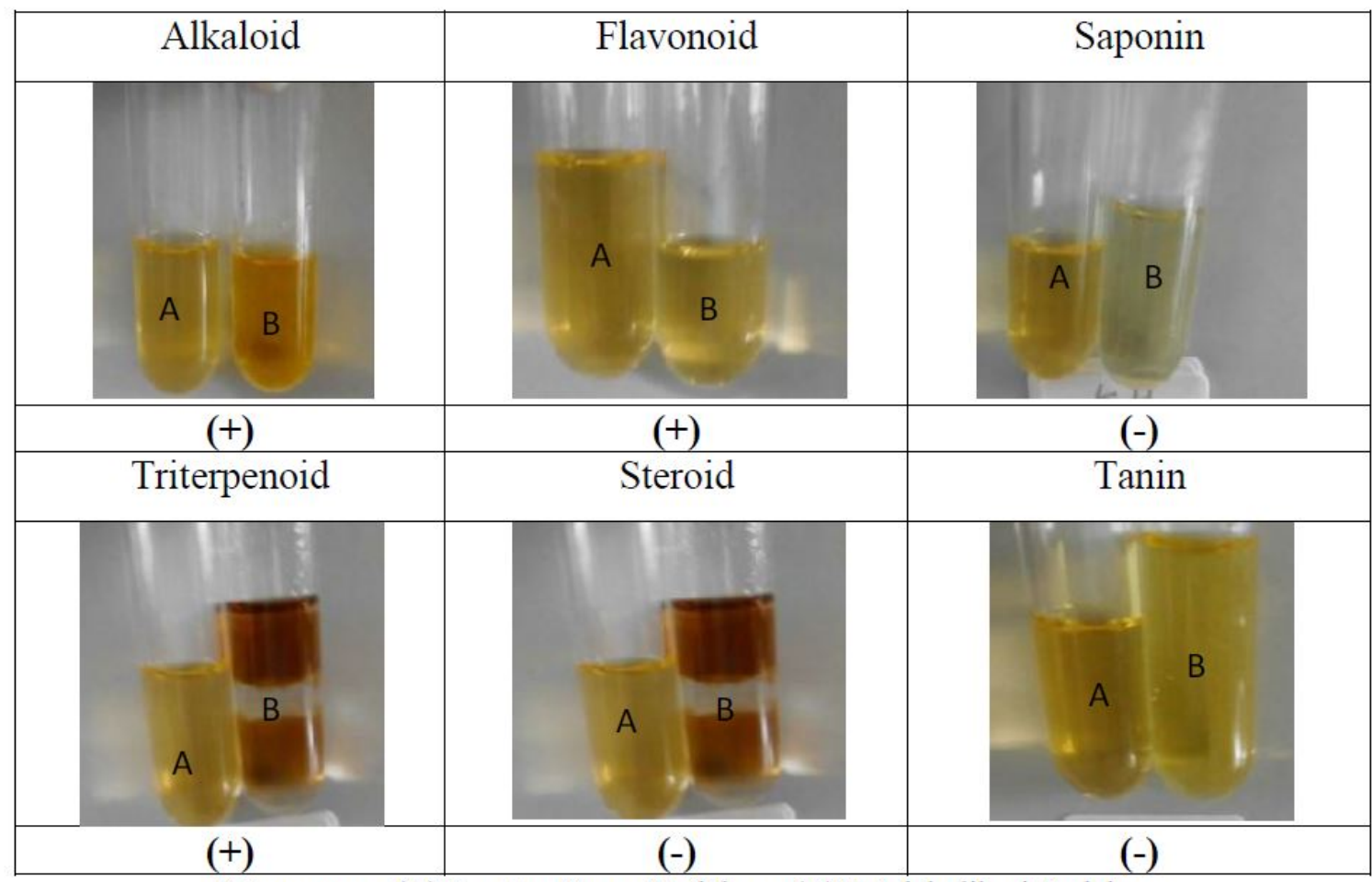

Keterangan : (A) Larutan Tanpa Perlakuan (B) Setelah diberi Perlakuan

Gambar 2. Hasil pengujian fitokimia ekstrak methanol daun P. reticulatus

Metabolit sekunder adalah senyawa kimia yang umumnya mempunyai kemampuan bioaktivitas dan berfungsi sebagai pelindung tumbuhan tersebut dari gangguan, misalnya gangguan hama. Senyawa metabolit sekunder telah banyak digunakan sebagai zat warna, racun, aroma makanan, obat-obatan dan sebagainya. Banyak jenis tumbuh-tumbuhan yang digunakan obat-obatan yang dikenal sebagai obat tradisional sehingga diperlukan penelitian tentang penggunaan tumbuhtumbuhan berkhasiat dan mengetahui senyawa kimia yang berfungsi sebagai obat. Identifikasi kandungan metabolit sekunder merupakan langkah awal yang penting dalam penelitian pencarian senyawa bioaktif baru dari bahan alam yang dapat menjadi bagian untuk sintesis obat baru atau bahan utama obat tertentu (Rasyid 2012).

Alkaloid dinyatakan positif alkaloid apabila larutan ekstrak terbentuk endapan setelah penambahan amonia $\mathrm{NH}_{3}$ - pekat, asam sulfat $2 \mathrm{~N} \quad\left(\mathrm{H}_{2} \mathrm{SO}_{4} \quad 2 \mathrm{~N}\right)$ serta penambahan larutan pereaksi meyer ataupun pereaksi dragendrof. Hasil analisis menunjukkan bahwa sample katuk hutan positif memiliki kandungan alkaloid.

Ningrum dkk. (2016) mengatakan bahwa senyawa alkloid merupakan senyawa organik terbanyak ditemukan di alam. Hampir seluruh alkaloid berasal dari tumbuhan dan ditemukan dalam berbagai bagian tanaman. Menurut Aniszewki (2007), alkaloid merupakan senyawa yang memiliki aktivitas antimikroba, yaitu menghambat esterase dan juga DNA dan RNA polimerase, juga menghambat respirasi sel dan berperan dalam interaksi DNA. Selain itu, alkaloid adalah senyawa kimia organik yang mengandung nitrogen heterosiklik dan kebanyakan dari senyawa ini bersifat toksik/beracun serta tidak memiliki bau yang sedap. Alkaloid dapat meningkatkan serapan 
nutrisi dan melancarkan peredaran darah, mengurangi rasa sakit dan menstimulasi sistem syaraf. Senyawa alkaloid juga dapat digunakan sebagai anti bakteri dan anti jamur (Rizwana et al. 2010).

Pengujian flavonoid pada jenis tumbuhan katuk hutan menunjukan hasil positif pada tumbuhan katuk hutan . Flavonoid merupakan grup fenolik yang tersebar secara luas didalam tumbuhan, berpotensi dan memiliki aktivitas anti-kanker yang tinggi. Flavonoid juga telah terbukti diketahui sebagai senyawa dengan efek farmakologi yang cukup tinggi misalnnya sebagai antibakteri, antioksidan, anti-inflanmasi dan anti-jamur pada salah satu metabolit sekundernya (Mbadianya et al. 2013; Rahimah et al. 2013). Manfaat lain dari flavonid antara lain adalah melindungi sel, memiliki hubungan sinergis dengan vitamin $\mathrm{C}$ (meningkatkan efektivitas vitamin C), mencegah keropos tulang, dan sebagai antibiotik (Subroto dan Saputro 2008). Selain itu, flavonoid juga dilaporkan berperan dalam pencegahan dan pengobatan beberapa penyakit lain seperti asma, katarak, diabetes, encok/rematik, migrain, wasir, dan periodontitis (radang jaringan ikat penyangga akar gigi). Penelitianpenelitian mutakhir telah mengungkap fungsifungsi lain dari flavonoid, tidak saja untuk pencegahan, tetapi juga untuk pengobatan kanker (Subroto dan Saputro 2008).

Sampel uji dinyatakan positif mengandung tanin apabila reaksi yang terjadi akibat penambahan 5 tetes pereaksi $\mathrm{FeCl}_{3} \quad 10 \%$ (Harborne 1987). Pada ekstrak kental katuk hutan membentuk warna hijau. Hasil pengujian senywa tannin memberikan hasil negatif hal ini disebabkan karena tidak terlihat reaksi pembentukan warna hijau pada sampel yang ditetesi pereaksi $\mathrm{FeCl}_{3}$ 10\%. Tanin secara umum didefinisikan sebagai senyawa polifenol yang memiliki berat molekul cukup tinggi (lebih dari 1000) dan dapat membentuk senyawa kompleks dengan protein.
Berdasarkan strukturnya, tanin dibedakan menjadi dua kelas yaitu tanin terkondensasi (condensed tannins) dan tanin terhidrolisiskan (hydrolysable tannins) (Hagerman et al. 1992 dalam Subroto dan Saputro 2008). Disebutkan dalam Harbone (1987) bahwa tanin terdapat luas dalam tumbuhan berpembuluh, sedangkan dalam angiospermae terdapat dalam jaringan kayu. Tanin berfungsi sebagai penghambat mikroba (antimikroba). Selain itu tanin juga berperan sebagai bahan perekat kayu, penyamak kulit, pengawet telur mentah, sebagai bahan pewarna alami. Tanin juga berfungsi untuk mengobati diare, menghentikan pendarahan dan mengobati ambeien (Subroto dan Saputro 2008).

Saponin dinyatakan positif apabila menghasilkan buih atau busa pada pemanasan menggunakan aquades. Pada pengujian saponin, menunjukan Negatif mengandung senyawa saponin pada tanaman katuk hutan. Padmasari et al. (2013) menyebutkan saponin merupakan metabolit sekunder yang sangat familiar untuk proses glikolisis dan merupakan senyawa aktif permukaan yang dapat menimbulkan busa jika dikocok dalam air. Hal tersebut terjadi karena saponin memiliki gugus polar dan non polar yang akan membentuk misel. Pada saat misel terbentuk maka gugus polar akan menghadap keluar dan gugus polar akan mengahdap kedalam. Keadaan ini yang akan tampak seperti busa. Selain itu juga karena gugus polar menghadap keluar, hal ini menyebabkan senyawa saponin mudah di ekstraksi di pelarut yang bersifat polar seperti etanol. Rizwana et al. (2010) juga melaporkan bahwa senyawa ini dipercaya dapat mengkontrol kolestrol pada proses diet, dan juga digunakan sebagai obat beberapa penyakit kuli (seperti ruam). Saponin juga bisa digunakan sebagai anti inflamasi serta digunakan untuk proses penyembuhan pada penyakit tuberkolosis. Selain itu saponin juga 
dapat digunakan dalam pengobatan sebagai bahan baku untul sintesa hormone steroid.

Hasil pengujian triterpenoid dan steroid ditandai dengan terbentuknya endapan atau adanya perubahan warna. Apabila terlihat warna merah dan ungu maka uji dinyatakan positif untuk senyawa triterpenoid dan apabila terlihat warna hijau dan biru maka dinyatakan positif adanya steroid. Senyawa triterpenoid positif terkandung dalam hasil ekstrak metanol daun $P$. reticulatus. Sedangkan senyawa steroid negatif terkandung dalam hasil ekstrak metanol dari daun katuk hutan. Senyawa triterpenoid biasanya mudah diisolasi jika terbentuk minyak atsiri. Hal ini sejalan dengan pendapat Lenny (2006) yang menyebutkan bahwa triterpenoid adalah komponen-komponen tumbuhan yang mempunyai bau dan dapat diisolasi dari bahan nabati dengan penyulingan disebut minyak atsiri.

Mbadianya et al. (2013) melaporkan bahwa steroid adalah senyawa yang memiliki aktivitas antibakteri dan merupakan senyawa yang memiliki peranan penting dalam perkebangan hormon. Steroid juga sebagai bahan baku pembuatan pil kontraseptik. Steroid anabolik dapat mengakibatkan sejumlah efek samping yang berbahaya seperti menurunkan rasio lipoprotein densitas tinggi, yang berguna bagi jantung, stimulasi tumor prostar, kelainan koagulasi dan gangguan hati, kebotakan dan tumbuhnya jerawat (Lenny 2006).

\section{Pengujian Antioksidan}

Dalam pengujian antioksidan masing-masing ektrak digunakan spektrofotometer UV-Vis untuk melihat serapan DPPH (1,1-diphenyl-2picrylhydrazyl) pada panjang gelombang 514 nm.DPPH merupakan suatu senyawa radikal bebas yang stabil dan dalam penggunaannya sebagai pereaksi dalam uji penangkapan radikal bebas. Pengujian yang dilakukan menggunakan ascorbic acid (vitamin C) sebagai kontrol positif. Pengujian antioksidan menggunakan ekstrak metanol daun katuk hutan dengan konsentrasi berturut-turut adalah $100 \mathrm{ppm}, 50$ ppm dan 25 ppm. Adapun hasil dari masingmasing pengujian yang telah dilakukan dapat dilihat pada gambar 2 .

\section{Grafik Aktivitas Ekstrak Metanol Terhadap DPPH (\%)}

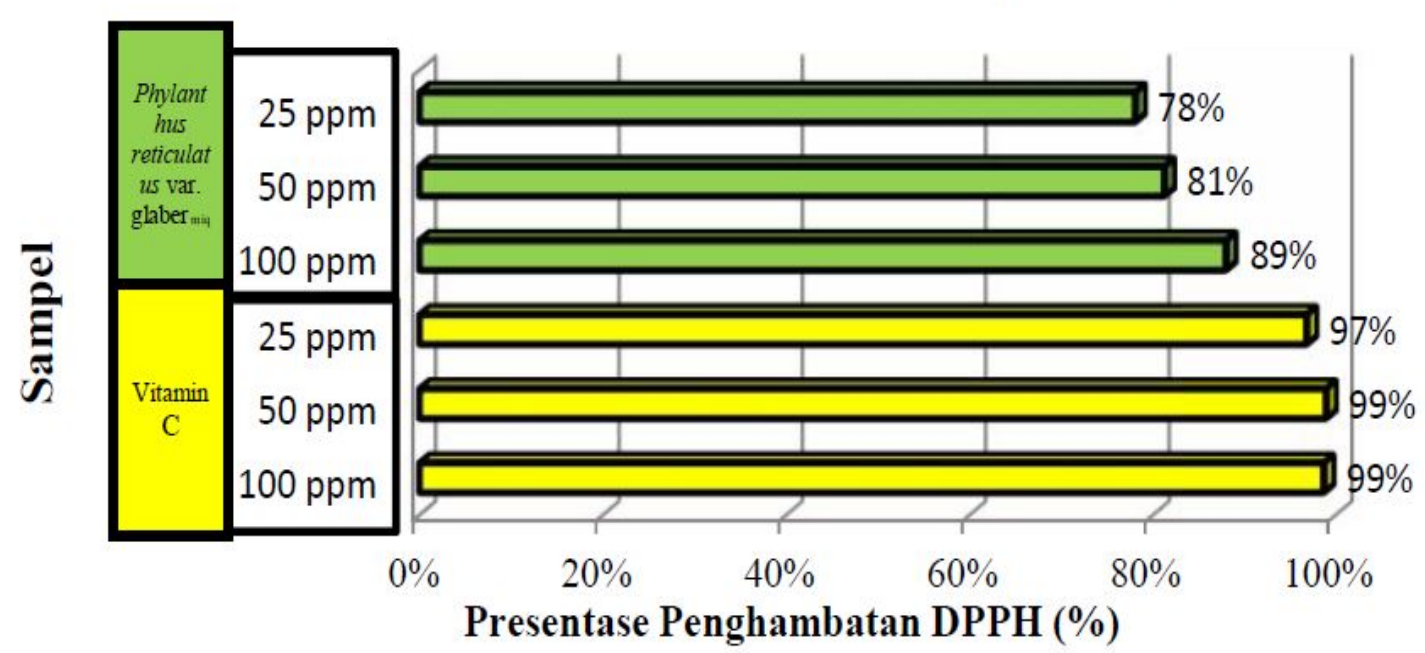

Gambar 3. Grafik aktivitas estrak metanol terhadap DPPH (\%) 
Gambar 3. menunjukan hasil pengujian antioksidan dari tanaman katuk hutan ekstrak metanol pada konsentrasi 100, 50 dan 25 ppm dengan menggunakan kontrol positif (vitamin C). Hasil yang didapatkan menunjukkan bahwa nilai aktivitas tertinggi ekstrak dau katuk hutan dalam menghambat DPPH mencapai 89\%. Pada konsentrasi 50 dan $25 \mathrm{ppm}$ aktivitas menghambat mencapai $81 \%$ dan $78 \%$.

\section{Kurva Regresi Linear Aktivitas Antioksidan Ekstrak Daun Phylanthus reticulatus var. Glaber}

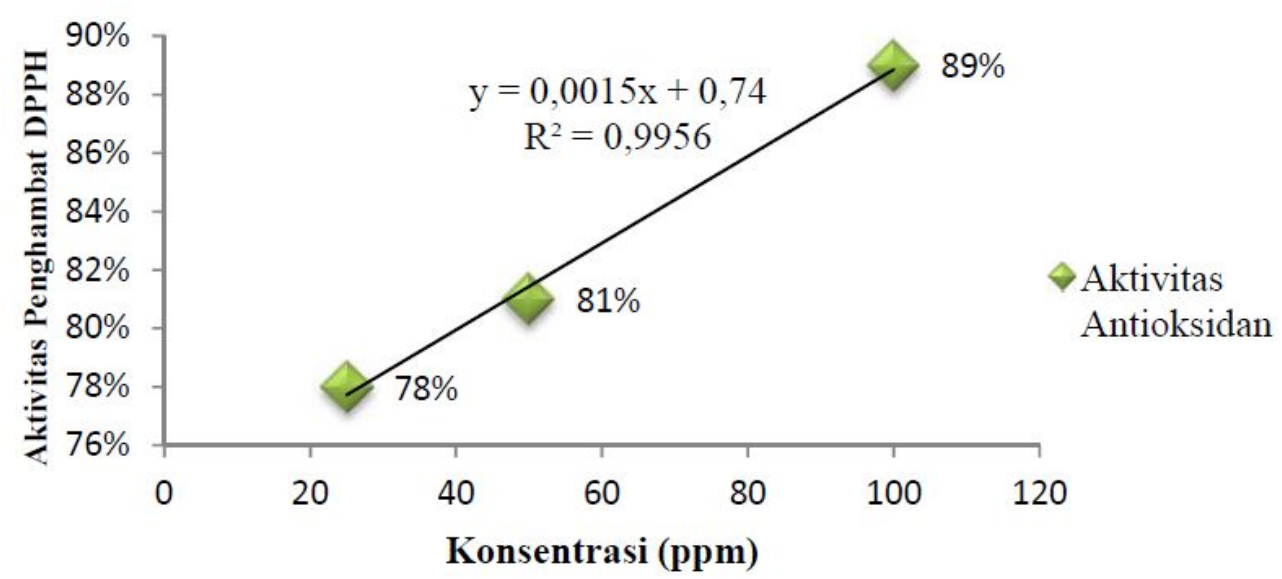

Gambar 4. Kurva regresi linier aktivitas antioksidan ekstrak daun katuk hutan

Perhitungan EC50 dilakukan dengan cara meninterpolasikan persen perendaman $(50 \%)$ kedalam kurva hubungan konsentrasi larutn uji dengan persen Aktivitas penghambatan DPPH. Dari gambar 10 diperoleh persamaan garis regresi $\mathrm{Y}=0,0015 \mathrm{X}+0,746$. Berdasarkan persamaan data di atas maka aktivitas penghambatan DPPH dipengaruhi oleh 0,0015 dari konsentrasi ekstrak daun katuk hutan ditambah faktor koreksi sebesar 0,746. Dengan demikin dapat diketahui nilai EC50 dengan memasukkan nilai 50 sebagai sumbu Y, sehingga dapat diperoleh berapa besar nilai $\mathrm{X}$ yang akan merepresentasikan besaran EC50 yaitu 37,88 ppm. Berdasarkan tabel 1 . Klasivikasi Aktivitas Antioksidan berdasarkan EC50. Oleh karena itu dapat dikatakan bahwa senyawa antioksidan dalam sampelekstrak daun katuk hutan diatas memiliki aktivitas antioksidan yang sangat kuat.
Berdasarkan hasil penelitian Arry dkk. (2011) nilai EC50 ekstrak kulit manggis sebesar 11,0825 ppm. Ekstrak kulit manggis diketahui memiliki aktivitas antioksidan yang sangat kuat. Jika dibandingkan dengan nilai EC50 Yang dimiliki ekstrak daun Katuk hutan keduanya berada dibawah 50 ppm yang termasuk dalam kelas aktivitas antioksidan yang sangat kuat. Oleh karena itu katuk hutan dapat dimanfaatkan sebagai senyawa antioksidan alami.

Gambar 3. memperlihatkan grafik peredaman DPPH yang di ujikan pada ekstrak metanol tanaman katuk hutan dengan konsentrasi 100, 50 dan 25 ppm, aktivitas peredaman DPPH dari tanaman katuk hutan sebesar $88 \%, 81 \%$ dan $79 \%$. Tanaman katuk hutan $P$. reticulatus dimanfaatkan oleh masyarakat papua sebagai obat-obatan tradisional. Pada pengujian fitokimia, $P$. reticulatus memiliki kandungan alkaloid, flavanoid, dan terpenoid. 
Senyawa flavonoid berperan sebagai penangkap radikal bebas. Flavonoid mampu bertindak sebagai antioksidan dan berfungsi menetralisir radikal bebas dengan demikian meminimalkan efek kerusakan pada sel dan jaringan tubuh. Radikal bebas adalah molekul yang sangat reaktif dan tidak stabil akibat telah kehilangan elektron. Untuk menstabilkan diri, radikal bebas memerlukan electron dan untuk mencapai tujuan ini kemudian mengoksidasi sel-sel sehat pada tubuh sehingga menyebabkan kerusakan. Radikal bebas terutama diproduksi sebagai produk samping dalam berbagai proses biokimia dalam tubuh. Flavonoid sebagai antioksidan membantu menetralisir dan menstabilkan radikal bebas sehingga tidak lagi merusak sel-sel dan jaringan sehat. Flavonoid memberi perlindungan terhadap sejumlah penyakit termasuk kanker, penyakit jantung, diabetes, tumor dan lainlain.

Flavonoid juga membantu mencegah aterosklerosis atau penyakit yang ditandai dengan pengendapan lemak dalam dinding arteri. Deposisi tersebut mempersempit arteri dengan demikian menghambat aliran darah keorgan-organ vital tubuh seperti jantung dan otak. Antioksidan dapat menurunkan resiko arthritis, osteoporosis, alergi dan penyakit virus. Flavonoid mampu menekan penggumpalan trombosit yang berhubungan dengan penyakit seperti aterosklerosis dan pembentukan trombosit akut trombus.

Senyawa Alkaloid juga dapat berperan dalam menyembuhkan kanker. Kanker merupakan penyakit yang disebabkan akibat kerusakan sel-sel jaringan. Kerusakan sel-sel jaringan disebabkan oleh produksi radikal bebas yang berlebihan dan produksi antioksidan yang tidak memadai. golongan alkaloid yang berperan dalam menyembukan kanker antarai lain adalah vicristin dan vinblastin.

Triterpenoid dapat merevitalisasi pembuluh darah sehingga predaran darah keotak menjadi lancar, memberikan efek menenangkan dan meningkatkan fungsi mental menjadi yang lebih baik. Menurut Sukadana dkk. (2008) dalam laporannya mengatakan bahwa kandungan triterpenoid limonen, terbukti efektif untuk mengatasi kanker payudara, kanker liver, kanker paru dan juga leukimia. Terpenoid lainnya, betakaroten, membantu merangsang kelenjar thymus untuk memproduksi lebih banyak sel limfosit $\mathrm{T}$ yang dapat langsung menghancurkan sel kanker. Sedang asam ursolat yang juga golongan triterpenoid dapat mencegah pertumbuhan sel abnormal (kanker) sekaligus menyuruh sel kanker yang sudah ada untuk mematikan dirinya sendiri.

\section{Pengujian Antibakteri}

Pengujian aktivitas antimiokroba menggunakan metode difusi berdasarkan Elkhair et al. (2010), yang sudah dimodifikasi dengan menggunakan aseton sebagai kontrol negatif (-) dan chloramphenicol sebagai kontrol $(+)$. Sampel ditimbang $5 \mathrm{mg}$, dan kemudian dilarutkan kedalam $1 \mathrm{ml}$ etanol $40 \%$ sebagai larutan stok. Sebanyak $50 \mu$ l sampel dimasukkan kedalam microplate 96 wells, kemudian konsentrasi diturunkan hingga mendapat konsentrasi akhir sebesar 50, 125, 250 dan $500 \mu \mathrm{g} /$ well. Setelah itu masukkan media agar dan larutan bakteri yang telah disuspensi dengan akuades sebanyak 100 dan $50 \mu 1$.

Sampel diuji terhadap bakteri Propionibacterium acnes, Streptoccocus mutans, Streptoccocus sobrinus, dan Escherichia coli. Warna merah menunjukkan adanya aktivitas bakteri yang masih hidup setelah penambahan Triphrnyl Tetrazolium Chloride $50 \mu 11$ jam sebelum proses inkhubasi selesai. Kemudian masukkan kedalam media padat pada cawan petri dengan menggunakan metode streak plate. Inkhubasi dilakukan selama sehari $1 \times 24$ jam untuk mengetahui tumbuh tidaknya bakteri (presentasi 
penghambatan zona bening) disajikan dalam

tabel 2, 3, 4 dan 5 berikut:

Tabel 2. Aktivitas antibakteri ekstrak katuk hutan terhadap Propionibacterium acnes

Sampel

\begin{tabular}{|c|c|c|c|c|c|c|c|}
\hline \multicolumn{8}{|c|}{ Aktivitas antibakteri pada berbagai konsentrasi $(\mu \mathrm{g} /$ well $)$} \\
\hline \multicolumn{2}{|c|}{50} & \multicolumn{2}{|c|}{125} & \multicolumn{2}{|c|}{250} & \multicolumn{2}{|c|}{500} \\
\hline $\mathrm{nm}$ & $\% \mathrm{ZN}$ & $\mathrm{nm}$ & $\% \mathrm{ZN}$ & $\mathrm{nm}$ & $\% \mathrm{ZN}$ & $\mathrm{nm}$ & $\% \mathrm{ZN}$ \\
\hline \multicolumn{8}{|c|}{0.00} \\
\hline & J & J & J & J & J & J & J \\
\hline
\end{tabular}

(

Ket : \% ZN= Persentase penghambatan zona bening

Tabel 3. Aktivitas antibakteri ekstrak katuk hutan terhadap Streptoccocus mutans

\begin{tabular}{|c|c|c|c|c|c|c|c|c|}
\hline \multirow[t]{3}{*}{ Sampel } & \multicolumn{8}{|c|}{ Aktivitas Antibakteri pada berbagai konsentrasi ( $\mu \mathrm{g} /$ well) } \\
\hline & \multicolumn{2}{|c|}{50} & \multicolumn{2}{|c|}{125} & \multicolumn{2}{|c|}{250} & \multicolumn{2}{|c|}{500} \\
\hline & $\mathrm{mm}$ & $\% \mathrm{ZN}$ & $\mathrm{mm}$ & $\% \mathrm{ZN}$ & $\mathrm{mm}$ & $\% \mathrm{ZN}$ & $\mathrm{mm}$ & $\% \mathrm{ZN}$ \\
\hline Aseton (-) & \multicolumn{8}{|c|}{0.00} \\
\hline Chloramphenicol (+) & \multicolumn{8}{|c|}{100} \\
\hline Katuk hutan & 0 & 0 & 0 & 0 & 0 & 0 & 0 & 0 \\
\hline
\end{tabular}

Ket : \% ZN $=$ Persentase penghambatan zona bening

Tabel 4. Aktivitas antibakteri ekstrak katuk hutan terhadap Streptoccocus sobrinus

\begin{tabular}{|c|c|c|c|c|c|c|c|c|}
\hline \multirow[t]{3}{*}{ Sampel } & \multicolumn{8}{|c|}{ Aktivitas Antibakteri pada berbagai konsentrasi ( $\mu \mathrm{g} / \mathrm{well})$} \\
\hline & \multicolumn{2}{|c|}{50} & \multicolumn{2}{|c|}{125} & \multicolumn{2}{|c|}{250} & \multicolumn{2}{|c|}{500} \\
\hline & $\mathrm{mm}$ & $\% \mathrm{ZN}$ & $\mathrm{mm}$ & $\% \mathrm{ZN}$ & $\mathrm{mm}$ & $\% \mathrm{ZN}$ & $\mathrm{mm}$ & $\% \mathrm{ZN}$ \\
\hline Aseton (-) & \multicolumn{8}{|c|}{0.00} \\
\hline Chloramphenicol (+) & \multicolumn{8}{|c|}{100} \\
\hline Katuk hutan & 0 & 0 & 0 & 0 & 0 & 0 & 0 & 0 \\
\hline
\end{tabular}

Ket : $\% \mathrm{ZN}=$ Persentase penghambatan zona bening

Tabel 5. Aktivitas antibakteri ekstrak katuk hutan terhadap Escherichia coli

\begin{tabular}{|c|c|c|c|c|c|c|c|c|}
\hline \multirow[t]{3}{*}{ Sampel } & \multicolumn{8}{|c|}{ Aktivitas Antibakteri pada berbagai konsentrasi ( $\mu \mathrm{g} / \mathrm{well})$} \\
\hline & \multicolumn{2}{|c|}{50} & \multicolumn{2}{|c|}{125} & \multicolumn{2}{|c|}{250} & \multicolumn{2}{|c|}{500} \\
\hline & $\mathrm{mm}$ & $\% \mathrm{ZN}$ & $\mathrm{mm}$ & $\% \mathrm{ZN}$ & $\mathrm{mm}$ & $\% \mathrm{ZN}$ & $\mathrm{mm}$ & $\% \mathrm{ZN}$ \\
\hline Aseton (-) & \multicolumn{8}{|c|}{0.00} \\
\hline Chloramphenicol (+) & \multicolumn{8}{|c|}{100} \\
\hline Katuk hutan & 0 & 0 & 0 & 0 & 0 & 0 & 0 & 0 \\
\hline
\end{tabular}

Ket : \% ZN= Persentase penghambatan zona bening

Pemberian antibakteri dalam jumlah yang berlebihan dan secara terus - menerus akan menyebabkan sel bakteri menjadi resisten. Pengujian yang dilakukan untuk mengetahui nilai konsentrasi hambat minimum dari suatu sampel uji antibakteri sangat penting karena selain bertujuan untuk meningkatkan efektifitas dari senyawa antibakteri tersebut juga bertujuan untuk mencegah timbulnya masalah resistensi bakteri karena penggunaan dosis yang berlebihan sehingga sel bakteri lama kelamaan akan menjadi kebal. 
Tabel 2, 3, 4 dan 5 di atas menunjukkan hasil yang diperoleh pada pengujian antibakteri dengan menggunakan ekstrak daun katuk yang diujikan pada terhadap bakteri Propionibacterium acnes, Streptoccocus mutans, Streptoccocus sobrinus, dan Escherichia coli memberikan hasil negatif. Dilihat dari persentase penghambat zona bening tanaman katuk hutan tidak memberikan daya hambat terhadap perkembangan bakteri Propionibacterium acnes, Streptoccocus mutans, Streptoccocus sobrinus, ataupun Candida albicans pada konsentrasi 50, 125, 250 dan $500 \mu \mathrm{g} / \mathrm{well}$. Jika diklasifikasikan penghambat bakteri ekstrak daun katuk hutan masuk dalam kelas tidak ada aktivitas. Hasil positif mengandung antibakteri ditunjukan pada control positif yang menggunakan chloramphenicol presentase penghambat zona bening memberikan daya hambat maksimum hingga $100 \%$ pada konsentrasi 50, 125, 250 dan $500 \mu \mathrm{g} /$ well. Berdasarkan tabel uji antibakteri tanaman katuk hutan tidak memiliki daya menghambat ataupun membunuh bakteri. Hal ini terkait dengan hasil pengujian fitokimia dimana ekstrak daun katuk hutan tidak mengandung senyawa saponin. Sedangkan beberapa golongan senyawa saponin dapat bekerja sebagai antimikroba.

\section{Pengujian Toksisitas}

Brine Shrimp Lethality Test (BST) adalah salah satu metode skrining untuk menentukan toksisitas suatu senyawa atau ekstrak secara akut dengan menggunakan hewan coba Artemia salina. Pada pengujian ini dimodifikasi dengan mengganti hewan uji larva Arternia salina menggunakan larva ikan mas (Cyprinus carpio). Daya toksisitas suatu senyawa dapat diketahui dengan menghitung jumlah kematian hewan uji dengan parameter lethal concentration 50 (LC50). Suatu ekstrak dinyatakan bersifat toksik menurut metode BST ini jika memiliki LC50 kurang dari $1000 \mu \mathrm{g} / \mathrm{ml}$. Jika hasil uji BST menunjukkan bahwa ekstrak tumbuhan bersifat toksik maka dapat dikembangkan ke penelitian lebih lanjut untuk mengisolasi senyawa sitotoksik tumbuhan sebagai usaha pengembangan obat alternatif anti kanker.

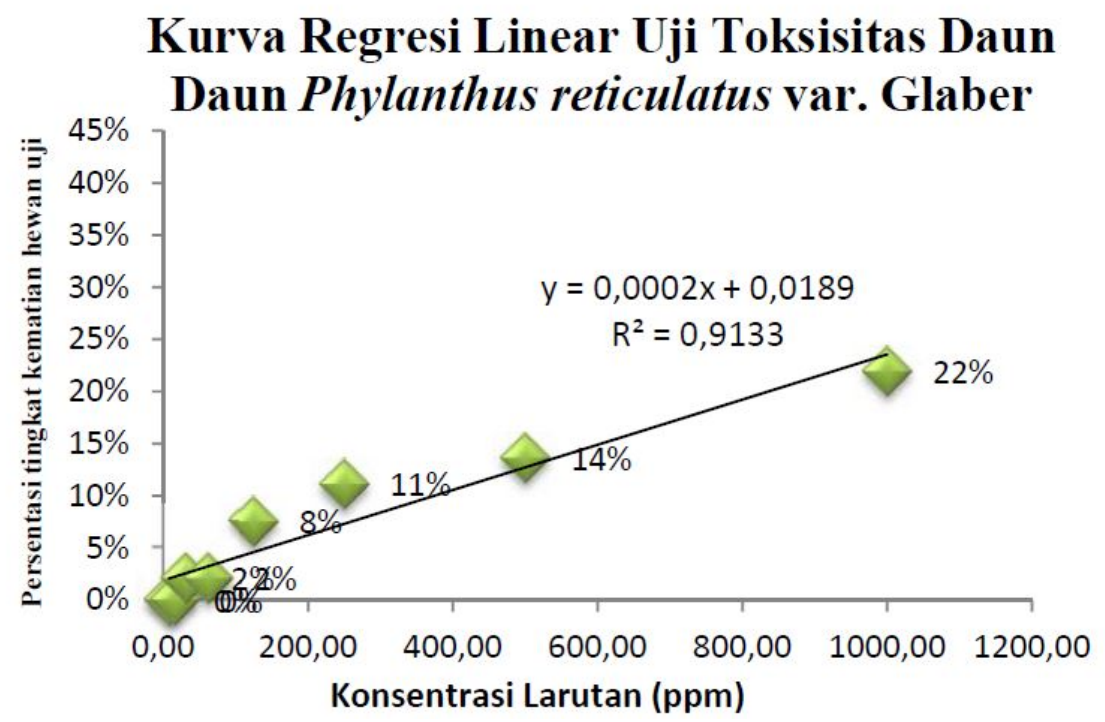

Gambar 11. kurva regresi linier uji tokisitas katuk hutan ekstrak methanol terhadap kematian larva Cyprinus carpio 
Berdasarkan hasil pengujian toksisitas ekstrak methanol katuk hutan dapat dilihat bahwa pada konsentrasi $1000 \mu \mathrm{g} / \mathrm{ml}$ memberikan persentase kematian sebesar $22 \%$. Oleh karena itu dapat dikatakan bahwa kandungan komponen bioaktif yang terkandung pada ekstrak methanol katuk hutan tidak memiliki daya racun yang berpotensi merusak. Berdasarkan hasil pengujian nilai LC50 dapat diperoleh dari persaman regresi $\mathrm{Y}=0.0002 \mathrm{X}+$ 0.0189 . Berdasarkan persamaan regresi yang diperoleh maka presentasi tingkat kematian hewan uji dipengaruhi oleh 0,0002 dari konsentrasi ekstrak daun katuk hutan dan ditambahkan dengan faktor koreksi sebesar 0,0189. Maka dengan demikian nilai dosis konsentrasi yang mematikan $50 \%$ oraganisme uji atau nilai LC50 dari ekstrak methanol katuk hutan mencapai 2402,748 $\mu \mathrm{g} / \mathrm{ml}$. Berdasarkan (Meyer et al. 1982 dalam Soemirat 2003) suatu senyawa uji dikatakan bersifat toksik dan berpotensi sebagai kandidat antikanker pada pegujian Brine Shrimp Lethality Tes (BST) jika memiliki nilai LC50-24 jam lebih kecil dari 1000 $\mu \mathrm{g} / \mathrm{ml}$. Hasil perhitungan pada penelitian ini diperoleh nilai $\mathrm{LC}_{50-24}$ jam mencapai 2402,748 $\mu \mathrm{g} / \mathrm{ml}$ lebih besar dari $1000 \mu \mathrm{g} / \mathrm{ml}$. berdasarkan nilai LC50 yang diperoleh ekstrak katuk hutan tidak bersifat toksit. namun diduga hasil pengujian yang diperoleh tidak akurat. Hal ini dikarenakan standar pengujian Brine Shrimp Lethality Test (BST) menggunakan hewan uji coba berupa larva Artemia salina (larva udang) sedangkan pengujian ini, hewan uji yang digunakan telah dimodifikasi menggunakan larva Cyprinus carpio (larva ikan mas). Maka untuk memperoleh hasil yang lebih akurat perlu dilakukan pengujian kembali mengunakan larva Artemia salina.

\section{KESIMPULAN}

Berdasarkan Hasil peenelitian yang telah dilakukan dapat disimpulkan bahwa rendemen ekstraksi metanol daun katuk hutan sebesar
$27,06 \%$ dimana hasil pengujian fitokimia menunjukkan bahwa ekstrak methanol daun $P$. reticulatus positif mengandung senyawa alkaloid, flavonoid dan triterpenoid. Selain itu dari hasil pengujian antioksidan dengan konsentrasi 25, 50 dan 100 ppm pada ekstrak methanol daun $P$. reticulatus memiliki daya hambat yang cukup tinggi mencapai $78 \%, 81 \%$ dan $89 \%$. Hasil pengujian ekstrak methanol daun $P$. reticulatus terhadap bakteri $P$. acnes, $S$. mutans, $S$. sobrinus, dan E. coli menunjukkan hasil negative menghambat zona perkembangan dari ke empat bakteri yang digunakan. Selanjutnya berdasarkan hasil pengujian toksisitas ekstrak methanol daun $P$. reticulatus dengan metode BST diperoleh nilai LC50 mencapai $2402,748 \mu \mathrm{g} / \mathrm{ml}$.

\section{DAFTAR PUSTAKA}

Agromedia. 2008. Buku pintar tanaman obat. Jakarta: PT. Agromedia Pustaka.

Aniszewki, T. 2007. Alkaloid-ecrets of life, Elsevier, Amsterdam, pp. 187.

Arifin, Helmi, Aggraini, Nelvi, Handyani, Dian, Rasyid, Roslinda. 2006. Standarisasi ekstrak etanol daun Eugenia cumini Merr.J. Sains Tek.Far. 11 (2).

Arry YIP, Miryanti dkk. 2011. Ekstraksi antioksidan dari kulit buah manggis (Garcinia mangostana L.), Universitas Katolik Parahyangan Bandung.

Elkhair EA, Fadda H, Mohsen UA. 2010. Antibacterial activity and phytochemical analysis of Ssome medicinal plants from Gaza Strip- Palestine. Journal of Al Azhar University.

Forest Watch Indonesia, 2015.Nasib hutan Indonesia. Forest Watch Indonesia. Bogor.

Harborne JB. 1987. Metode fitokimia. Terjemahan: Padmawinata, K dan Soediro, I. Institut Teknologi Bandung, Bandung.

Joyeux M, Mortier F, Fleurentin J. 1995. Screening of antiradical, antilipoperoxidant and hepatoprotective effects of nine plant 
extracts used in Caribbean folk medicine. Phytotherapy Research. 9(3): 228-230. DOI: https://doi.org/10.1002/ptr.2650090316

Keputusan Mentri Kesehatan Republik Indonesia Nomor : 381/Menkes/SK/III/2007. Kebijakan obat tradisional nasional tahun 2007. Departemen Kesehatan Republik Indonesia. Tanggal 27 Maret 2007.

Kurdi A. 2010. Tanaman herbal Indonesia; cara mengelolah dan manfaatnya bagi kesehatan.

Hairani, Rita, Enih R, Kuspradini H. 2012. Phytochemical screening and brine shrimp lethality test of extract from avicennia lanata ridley leaves . Proceeding the International Symposium on Human Development and Sustainable Utilization of Natural Resources in Asian Cauntries and The 6thKoreaThailand-Indonesia Joint Symposium on Biomass Utilization and Renewable Energy, Balikpapan-Derawan Island.

Lenny S. 2016. Senyawa terpenoida dan steroida. Karya Ilmiah. Fakultas Matematika dan Ilmu pengetahuan Alam Universitas Sumatra Utara.

Mbadiyana JI, Echezona BC, Ugwuoke KI, Wokocha RC. 2013. Phytochemical constituens of some medical plants. International Jurnal of Science and Research. Vol. 2 (4): 18-22.

Ningrum R, Purwanti E, Sukarsono. 2016. Identifikasi senyawa alkaloid dari batang karamunting (Rhodomyrtus tomentosa) sebagai bahan ajar biologi untuk SMA kelas $\mathrm{X}$. Jurnal Pendidikan Biologi Indonesia. 2(3): 231-236.

Padmasari PD, Astuti KW, Warditani NK. 2013. Skining fitokimia ekstrak etanol $70 \%$ rimpang bangle zigiber purpureum Roxb. Jurnal Farmasi Udayana.
Prolab Diagnostics. 2012. McFarland standards. Product Code SD2350, SD2300, SD2301, SD2302, SD2303, SD2304.

Rahimah, Sayekti E, Jayuska A. 2013. Karakterisasi senyawa flavonoid hasil isolat dari fraksi etil aset6at daun matoa Pometia pinnata J. R. Frost \& G. Forst. JKK. Vil. 2 (2): 84-89.

Rasyid A. 2012. Identifikasi senyawa metabolit sekunder serta uji aktivitas antibakteri dan antioksidan ekstrak metanol teripang stichopus hermani. Jurnal Ilmu dan Teknologi Kelautan Tropis. Vol 4 (2):360 365.

Rizwana J.N, Nazlina I, Razehar ARM, Noraziah AZS, Ling CY, Muzaimah SAS, Farina AH, Yaacob WA, Ahmad IB, Din LB. 2009. A survey on phytochemical and bioactivity of plant extracts from Malaysian Forest Reserves. Journal of Medicinal Plants Reserch. Vol 4 (3): 203-210.

Shimizu Y, Inoue A, Tomari Y, Suzuki T, Yokogawa K, Nishikawa K, Ueda T. Cellfree translation reconstitute with purified components. Nature Biotechnology. 19: 751755. DOI: $10.1038 / 90802$

Soemirat J. 2003. Toksikologi lingkungan. Universitas Gajah Mada. Yogyakarta.

Subroto A, Saputro H. 2008. Gempur penyakit dengan sarang semut. www..deherba.com (19 Juni 2016).

Sukadana I, Santi SR, Juliarti NK. 2008. Aktivitas antibakteri senyawa golongan triterpenoid dari biji papaya (Carica papaya L). Jurnal Kimia. 2(1): 15-18.

Tihel T. 1999. Science in the real world. Microbes in Action. Departement of Biology, University of Missouri. St. Louis. 